\title{
Pengabdian Masyarakat Pemberdayaan Kapabilitas Wirausaha Dan Penerapan Biosekuritas Pada Usaha Peternakan Ayam Pedaging Desa Pucangan Kabupaten Sukoharjo
}

\author{
Arif Julianto Sri Nugroho ${ }^{1}$, M Pujo Darmo ${ }^{2}$, Endang Eko Djati Setiawati ${ }^{3}$, \\ Darupratomo ${ }^{4}$, Agung Nugroho Jati ${ }^{5}$, Tasari ${ }^{6}$, Abdul Haris ${ }^{7}$ \\ Universitas Widya Dharma Klaten \\ Email korespondensi: ${ }^{1}$ arifjuliantosn@unwidha.ac.id
}

\begin{abstract}
Abstrak: Berbagai virus patogen merupakan masalah utama bagi usaha peternakan ayam di Indonesia yang menyebabkan menurunnya profitabilitas. Wabah virus di kandang merupakan faktor utama kerugian usaha peternak ayam. Kegiatan pengabdian masyarakat program studi bagi dosen ini bertujuan meningkatkan kapabilitas wirausaha serta memperbaiki mutu pengelolaan kesehatan kandang melalui penerapan biosekuritas. Model kegiatan yang dilakukan meliputi: 1 ) Pengembangan kapabilitas wirausaha melalui literasi pengetahuan peternak terhadap aspek aspek manajemen usaha dan 2) Transfer Literacy teknologi biosekuritas kandang. Dari kegiatan diperoleh hasil positif dimana peternak sebagai pembelajar antusias untuk mengikuti program pemberdayaan kapabilitas wirausaha. Peternak mengalami peningkatan pengetahuan manajemen usaha dan bermuara pada terbentuknya pengetahuan baru pengelolaan usaha serta perbaikan sistem biosekuritas kandang pelaku usaha ternak ayam di lingkungan di Desa Pucangan
\end{abstract}

Kata kunci: abdimas, aspek manajemen, biosekuritas, usaha ternak ayam

Abstract: Various pathogenic viruses are a major problem for poultry farming in Indonesia, which causes a decline in profitability. Virus outbreaks in cages are a major factor in the loss of chicken farmers' business. This community service activity for lecturers in the study program aims to improve entrepreneurial capabilities and improve the quality of cage health management through the application of biosecurity. The model of activities carried out includes: 1) Development of entrepreneurial capabilities through farmer knowledge literacy on aspects of business management and 2) Literacy transfer of cage biosecurity technology. From the activity, it was obtained positive results where breeders as learners were enthusiastic about participating in the entrepreneurial capability empowerment program. Breeders experience an increase in business management knowledge and it leads to the formation of new knowledge of business management and improvement of the cage biosecurity system for chicken livestock business actors in the neighborhood in Pucangan Village.

Keywords: community service, management aspects, biosecurity, chicken livestock business

\section{PENDAHULUAN}

Pandemi Covid-19 saat ini sudah satu setengah tahun mendera semua sektor ekonomi di Indonesia. Pelaku industri perunggasan terutama peternak ayam mandiri menutup tahun 2020 dengan senyum kecut. Peternak tersenyum karena di tahun 2021 mulai muncul tanda- tanda bergairah industri peunggasan di tanah air melalui harga daging ayam hidup (lifebird) di peternak membaik dalam beberapa bulan terakhir. Namun, perbaikan harga masih belum mampu menutup kerugian peternak dari kenaikan ongkos berternak yang terus 
bertambah dari sisi pakan, obat obatan, harga ayam sehari (DOC) maupun ongkos tenaga kerja (Trubus, 2021)

Menteri Keuangan Sri Mulyani Inderawati meyakini ekonomi Indonesia di tahun 2021 akan tumbuh sebesar 5 persen. Beberapa kalangan masih belum yakin Indonesia belum sepenuhnya akan pulih dari resesi akibat pandemi Covid19 karena target vaksinasi bagi mayoritas masyarakat belum sepenuhnya terpenuhi sesuai rencana. Sejumlah bisnis seperti hotel, restoran dan katering yang selama ini banyak menyerap produk unggas, di tahun 2021 aktivitas kegiatan ini masih harus dibatasi

Selain akibat pandemi Covid-19, industri peternakan di Jawa Tengah saat ini menghadapi persoalan berulang dan belum menemukan solusi yang tepat dan meyeluruh. Pelaku usaha masih terbebani kerugian akibat kelebihan pasokan yang menyebabkan harga jual ayam jatuh. Bisnis yang masih memiliki prospek saat pandemi adalah bisnis kesehatan dan teknologi informasi. Bisnis ayam dengan diberlakukan PPKM berjilid jilid dengan tutupnya hotel, restoran dan café, ditutupnya pasar, ditiadakan seminar secara langsung jelas mengacaukan produk akhir ayam. Bisnis pembibitan ayam sangat berkaitan dengan permintaan ayam hidup (Trobos utama, 2020).
Merujuk pertumbuhan ekonomi kuartal ketiga 2020 sebesar minus 3, $49 \%$ ternyata sektor pertanian masih tumbuh positif sejumlah $2.15 \%$ (BPS, 2020). Untuk kesekian kali, berulang pada berbagai krisis ekonomi atau resesi, ketangguhan sektor pertanian sebagai penyelamat ekonomi bangsa telah teruji. Mengapa hal ini bisa terjadi, pangan adalah kebutuhan primer dan esensial bagi seluruh masyarakat. Kebutuhan ini tidak bisa ditunda baik pada saat pandemi maupun pada kondisi normal. Justru pada saat pandemi masyarakat dianjurkan untk mengonsumsi banyak makan bernutrisi yang bisa mendongkrak imunitas tubuh. Imunitas merupakan benteng utama dalam melawan penyebaran virus korona.

Salah satu upaya untuk meningkatkan ketahanan pangan adalah melalui penganekaragaman pangan berbasis peningkatan produksi sektor peternakan. yaitu suatu proses pengembangan produk terutama unggas yang mencakup segala aspek proses budidaya ternak unggas, produksi, variasi olahan daging unggas, distribusi hingga konsumsi ditingkat rumah tangga.

Saat ini kegiatan bisnis unggas baik produksi, budidaya terkait dengan aneka olahan pangan berbasis unggas di Pucangan cukup marak. Hal ini tentu merupakan satu bentuk langkah nyata dari apa yang 
diharapkan oleh Pemerintah Daerah dalam mewujudkan penganekaragaman potensi pangan lokal berbasis aneka olahan daging unggas yang menjadi ciri khas daerah Sukoharjo. Berdasarkan observasi awal diketahui bahwa di wilayah Desa Pucangan Kecamatan Kartosuro terdapat beberapa masyarakat yang memiliki usaha peternakan ayam pedaging secara mandiri.

Selama ini kegiatan pemasaran produk peternakan dan aneka olahan daging unggas dilakukan di pasar pasar di Kecamatan Kartosuro, Kota Surakarta dan kantin kantin sekolah, Universitas Muhammmadiyah Surakarta, IAIN Surakarta. Pemerintah Desa Pucangan dengan anggaran dana desa membuat tempat penampungan kuliner di Desa Pucangan dekat kampus IAIN Surakarta. Dengan perhatian dari Pemerintah Desa yang membuat los/ shelter area kuliner desa dengan olahan makanan dan jajanan berbasis pangan lokal daging unggas tentu perlu ditanggapi dengan serius dan sekaligus sebagai suatu peluang yang harus ditangkap.

Berdasarkan pengamatan selama ini beberapa produksi ternak ayam mandiri dan aneka olahan pangan lokal berbasis daging unggas warga Pucangan masih belum berkembang, diantaranya: 1) kualitas dan kuantitas masih perlu ditingkatkan, fasilitas produksi terutama kesehatan kandang kurang memadai, 2) pemasaran yang belum begitu luas dan 3) manajemen keuangan kurang tertata baik. Hal ini menjadi satu masalah yang perlu dicarikan solusi. Di satu sisi perlu langkah segera untuk menangkap peluang yang ada. Perlu adanya modernisasi produksi kandang, peningkatan kesehatan kandang dan peningkatan pengetahuan aspek aspek manajemen peternak. Modernisasi peningkatan aspek kesehatan kandang melalui penerapan biosekuritas kandang dan pemahaman aspek manajemen usaha bagi kelompok peternak mandiri di desa Pucangan bisa dilakukan.

Selama ini mitra kalangan peternak ayam di desa Pucangan telah berhubungan baik dengan Pemerintah Desa Pucangan. Namun hubungan tersebut sebatas memberikan informasi kepada mitra kegiatan-kegiatan program desa. Mitra sangat berharap pihak perguruan tinggi agar dapat memberikan bantuan baik berupa pelatihan, penerapan teknologi sederhana biosekuritas kandang, perbaikan manajemen keuangan, sistem pemasaran yang efektif sehingga dapat meningkatkan produktivitas usaha mikro pagi peternak di Desa Pucangan.

Kegiatan pengabdian ini memiliki nilai kebaruan pada analisis kegiatan yang didasarkan pada apa yang menjadi keinginan, kebutuhan yang diminta mitra 
sebagai upaya yang mampu diselesaikan pada persoalan mitra di lapangan.Tujuan pengabdian secara nyata adalah tumbuhnya kapabilitas manajemen pemasaran, keuangan dan teknologi biosekuritas kandang pada mitra peternak ayam pedaging Desa Pucangan Kabupaten Sukoharjo

\section{RUMUSAN MASALAH}

Dari analisis situasi di atas, ada beberapa masalah khusus yang dihadapi oleh mitra kelompok Peternak di desa Pucangan. Masalah pertama yaitu adalah pemasaran, perlu ditata dan ditingkatkan sehingga jaringan pemasaran modern menjadi semakin luas serta manajemen keuangan usaha yang menggunakan sistem yang sederhana, belum melakukan pembukuan yang rutin, rapi dalam pencatatan cash flow sehingga laporan neraca, rugi laba, perubahan arus kas menjadi tidak jelas. Untuk itu perlu pembenahan sistem manajemen keuangan bagi peternak mandiri.

masalah kedua manajemen kesehatan kandang yang masih kurang sehingga perlu diterapkan manajemen biosekuritas

\section{METODE KEGIATAN PENGABDIAN}

Memperhatikan luaran kegiatan yang hendak dicapai, maka metode kegiatan yang akan digunakan untuk mengatasi permasalahan melalui metode action research. Metode ini dilakukan melalui dua kegiatan yaitu (1) pengumpulan data melalui survei lapangan, (2) program pemberdayaan melalui penyuluhan, pelatihan dan pendampingan, yaitu pertemuan secara berkala antara pendamping dengan kelompok sasaran. Model pelaksanaan kegiatan dilakukan meliputi (Harjito dan Golda, 2018) : Model pemberdayaan kapasitas wirausaha dan transfer pengetahuan teknologi biosekuritas kandang

a. Model Pemberdayaan Kapasitas Wirausaha ilmu Manajemen

Model pemberdayaan kapasitas wirausaha digunakan untuk meningkatkan kemampuan kewirausahaan bagi peternak mandiri. Program dilakukan melalui pemberdayaan dan pendampingan. Pihak Perguruan Tinggi berfungsi sebagai motivator, inovator, fasilitator dan komunikator dari kegiatan. Analisis kemampuan mitra memahami kegiatan dijabarkan dari kuesioner sebelum dan sesudah kegiatan serta dilakukan analisis

\section{b. Model Transfer Teknologi dan}

\section{Pengetahuan}

Penemuan-penemuan hasil penelitian dan atau kegiatan lain dari Perguruan 
Tinggi dapat diterapkan kepada masyarakat secara tepat guna. Selanjutnya, dilakukan pelatihan teknologi tepat guna biosekuritas kandang yang diharapkan mampu peningkatkan mutu kesehatan kandang yang bermuara pada meningkatnya omset dan profitabilitas usaha ternak ayam mandiri.

\section{c. Target dan Luaran}

Dari kegiatan diharapkan diperoleh 1) meningkaynya kemampuan masyarakat untuk mewujudkan Visi dan Misi Pemerintah Kabupaten Sukoharjo yaitu Sukoharjo sejahtera bagi seluruh masyarakatnya. 2) meningknya penghasilan dan profitabilitas yang diterima oleh kelompok sasaran mitra peternak mandiri dimana semakin meningkat mutu kesehatan kandang melalui Biosekuritas Kandang. Peternak mandiri semakin meningkat pengetahuan pembelajar dari aspek aspek manajemen usaha ternak ayam modern.

Target luaran adalah adanya perubahan omset penjualan ayam pedaging sebelum dan sesudah kegiatan.
IV HASIL PENGABDIAN DAN

PEMBAHASAN

a. Pemberdayaan Kapabilitas Wirausaha berbasis Pengetahuan Aspek-aspek Manajemen

Kegiatan pelatihan dilakukan secara terstruktur berupa pemberian materi, tanya jawab, pemberian tugas-tugas, case study serta bermain peran (role playing). Kegiatan pelatihan dilaksanakan selama dua hari penuh berupa pelatihan knowledge aspek aspek manajemen usaha, problem solving, pengetahuan akses pasar, analisis modal kerja, produk dan pemasaran, kelayakan bisnis, pembentukan bisnis model serta solusi pemecahan masalah ternak unggas.

Aspek Pemasaran modern yang diberikan meliputi konsep lingkungan bisnis usaha ternak ayam potong mandiri, segmentasi pasar, targeting, posisioning serta strategi pemasaran modern daring usaha ternak di era Covid-19 (Mashuri, 2019). Dasar dari ilmu pemasaran adalah segala upaya, kegiatan pelaku usaha untuk memuaskan konsumen

Aspek keuangan diberikan dalam pelatihan kepada kepada mitra meliputi dasar-dasar ilmu manajemen keuangan, dasar- dasar akuntansi, konsep neraca dan laporan Rugi Laba dan metode arus kas. Mitra diharapkan mampu menyusun buku cash flow atau aliran kas yang memuat 
investasi atau capital outlays serta proceed atau cash inflo (Sunarjanto et.al, 2016). Kegiatan ini akan bermuara kepada meningkatnya kemampuan mitra menyusun studi kelayakan usaha.

Meningkatnya kemampuan mitra dapat dimonitoring saat praktek nyata dalam membuat analisis investasi usaha dan bisa menarik bank dan lembaga kredit resmi lain untuk menambah modal usaha. Hal ini bisa dilakukan karena usaha mitra dinilai feasibel oleh pihak Bank. Kemampuan mitra memahami kegiatan dilakukan evaluasi dari kuesioner sebelum dan sesudah kegiatan serta ditarik suatu simpulan

\section{b. Pelatihan Biosekuritas kandang}

Biosekuritas menurut Winkel (1997) merupaka suatu sistem untuk mencegah penyakit baik klinis maupun subklinis, mengoptimalkan produksi unggas keseluruhan yang bermuara pada meningkatnya kesejahteraan hewan (animal welfare). Kegiatan ini merupakan upaya praktis untuk mencegah organisme penyakit (patogen) dari luar ke kandang.

Pelaksanaaan kegiatan program biosekuritas meliputi (Hadi, 2019) : Kontrol lalu lintas, vaksinasi ayam, pencatatan riwayat Flok, Pencucian kandang ayam, kontrol terhadap pakan, kontrol terhadap air, kontrol terhadap limbah kotoran ayam serta ayam mati
Uji kuantitatif dari kuesioner yang dibagikan sebelum dan sesudah kegiatan melalui uji regresi diperoleh persamaan nilai positif yang memiliki arti apabila ada kenaikan satu satuan kegiatan pelatihan akan meningkatkan motivasi wirausaha peternak sebesar 0.60 satuan. Nilai uji korelasi diperoleh poin sebesar 0.782, artinya kegiatan ini memiliki pengaruh sangat kuat. Dari uji t diperoleh probabilitas 0.000. Artinya kegiatan pelatihan wirausaha peternak berpengaruh positif dan signifikan dalam menumbuhkan minat wirausaha. Hasil uji koefisien determinasi sebesar 0.625 artinya kegiatan pelatihan motivasi wirausaha peternaki memiliki pengaruh $62 \%$ terhadap meningkatnya minat wirausaha, sedangkan $38 \%$ faktor lain bisa diteliti dalam pelatihan tahap lanjut.

Kegiatan lapangan bersama mitra di dokumentasikan dalam gambar 1

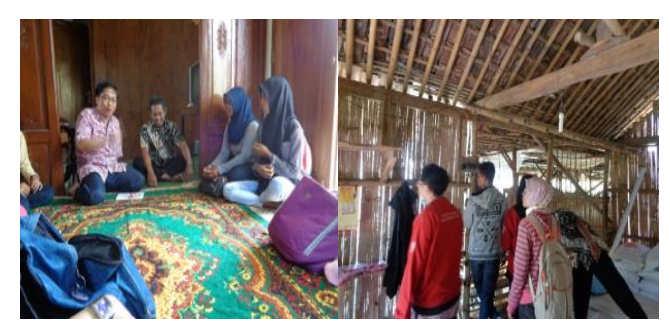

Gambar 1.Monitoring biosekuritas kandang

\section{SIMPULAN}

Pada tahap akhir kegiatan diambil simpulan bahwa Pengabdian Masyarakat dosen Program Studi di desa Pucangan mendapat respon positif dari mitra dan 
Pemerintah Desa Pucangan. Hasil yang dicapai diantaranya menguatnya pemahaman dan praktek kapabilitas wirausaha mitra melalui pengetahuan tata kelola manajemen usaha ternak ayam yang baik.

Hasil nyata kegiatan diperoleh temuan dalam monitoring, omset peternak bertambah naik dua kali dibanding dengan sebelum kegiatan selama dua kali panen ayam pedaging. Disamping itu telah diperoleh pemahaman dan praktek positif biosekuritas kandang yang bermuara pada menurunnya ayam mati, meningkatnya profit serta bertambahnya omset usaha.

Pemberdayaan masyarakat melalui peningkatan kemampuan wirausaha di desa Pucangan tidak cukup dilakukan dalam waktu singkat, melainkan dibutuhkan waktu panjang dan berkesinambungan. Untuk menjamin keberlanjutan program, perlu dilakukan pendampingan yang terarah dan kontinyu. Pendampingan dapat dilakukan baik oleh Perguruan Tinggi maupun melibatkan mitra konsultan. Partisipasi aktif mitra usaha di Desa Pucangan sebagai pelaku utama kegiatan pemberdayaan perlu terus dilakukan.

Sebagai upaya untuk semakin fokus kegiatan pendampingan dan mengalami keberlajutan, perlu dirancang Desa Pucangan sebagai Desa Binaan Universitas
Widya Dharma Klaten yang dilegalisasi melalui Surat Keputusan Rektor

\section{UCAPAN TERIMA KASIH}

Ucapan terima kasih disampaikan kepada pihak PPM Universitas Widya Dharma Klaten atas fasilitasi skim Abdimas Prodi dan publikasi luaran tahun 2021.

\section{DAFTAR PUSTAKA}

BPS, 2020. Laporan Akhir Tahun, www.BPS.go.id

Hadi, U.K. 2017, Pelaksanaan Biosekuritas pada Peternakan Ayam, Laporan Paper: Bogor: IPB FKH

Hardjito, D.A., Golda, N. 2018. KKN-PM Pengembangan Desa Wisata Somongari di Kabupaten Purworejo. AJIE-Asian Journal of Innovation and Entrepreneurship, Vol 03 No 03 hal 238-245

Mashuri. 2019. Analisis Strategi Pemasaran UMKM di era 4.0. Iqtishaduna, Jurnal Ekonomi, vol 8 (2) hal 215 224

Sunarjanto, W.A, Roide, H.Y., Widyaningndyah, A.V. 2016. Analisis Rasio Keuangan untuk Memrediksi Kegagalan Bisnis Usaha Kecil dan Mikro, Jurnal Bisnis dan Ekonomi, Vol 23 (2) hal 152-161

Trobos Utama.2020. Masa Depan Peternakan, Trobos Livestock .com/detailberita/2020/09/01/7/13385/masadepan-peternakan

Trubus, 2021. Potret Pasar Unggas, Majalah Bulanan, edisi januari 2021 hal 42-45

Wingkel, P.T.1997. Biosecurity in Poultry Production: Where are we and where do we go? Prosiding $11^{\text {th }}$ 
Patria : Jurnal Pengabdian Kepada Masyarakat

ISSN : 2656-5455 (media online) Vol. 3 | No. 2 September 2021

International Congress of The world

Poultry Association 